\title{
ACCESSORY MINERALS AS INDICATORS OF DEPTH OF MAGMA GENERATION AND ORE GENESIS WITHIN DASHKESAN ORE REGION (LESSER CAUCASUS, AZERBAIJAN)
}

\author{
Ismail-zadeh A.J., Kangarli T.N., Akhmadov A.M., Amirov A.S. \\ Institute of Geology and Geophysics of Azerbaijan National Academy of Sciences \\ 119, H. Javid av., Baku, AZ1143, Azerbaijan: arifismail@mail.ru, \\ tkangarli@gmail.com,ahmedov.geo@gmail.com
}

Keywords: Jurassic magmatism, scoria, native iron, wustite, spinifex structure
Summary. Wustite (for the first time defined by authors in the territory of Azerbaijan) and native iron are found in the slag-like fragments of rocks (scorias) contained in the river alluvium above flood-plain terraces of Ganjachay and its small tributaries within the eastern periphery of Dashkesan trough (Lok-Garabagh zone of Lesser Caucasus). They represent following two types of burnt, dense and lumpy bubble-rocks: 1 - basaltoids with typical spinifex structure and native iron and magnetite content; 2 - granitoids with impregnations of the different-size fragments of wustites, as well as magnetites, maghemites, etc. First type of the metal-bearing rocks corresponds to low-titanium and komatiite-like ferro-magnesian formations (pyroxene komatiites - ?), while the second type is represented by diorites-quartz diorites. Materials of the conducted research bring us to a conclusion that wustite and other metal-bearing formations are brought to a daylight through the hybrid magma with quartz-diorite composition which have formed through mixing of the palingenic granitoid magma with the serpentized rocks of buried ultrabasic plate. Studied samples represent fragments of a deep magmatic focus - ultrabasic rocks that had been recrystallized into komatiites (?) as well as fragments of the marginal zones of magma generation focus, e.g. melted granitoids with wustite, magnetite, maghemite, etc., ejected by an explosive activity of paleo volcanoes.

(C) 2019 Earth Science Division, Azerbaijan National Academy of Sciences. All rights reserved.

\section{Introduction}

The most important process related to an emergence of the ore-metallogenic systems is the identification of genetical basis of their primary sources, including differentiation of parental substance, palingeny, polynchronousness and liquation of melt, which can be strengthened by gas components. These processes used to be most active in the earth crust's deeper horizons, but they also could have occurred in the lower hypsometrical levels of the magmatic pocket location.

Rocks with different composition could have formed because of either assimilation or mixture of two independent melts not connected with each other by a common magmatic pocket. One of these rocks could have a sheet mantle composition, while the other could emerge as a result of palingeny in the lower parts of the granitic layer. This very factor is a key for determining a depth of the ore genesis processes that are typical for the Mediterranean metallogenic province. This statement can be ex- emplified by the ore-magmatic system of Dashkesan ore field.

In a tectonic scheme of Lesser Caucasus region, most payable types of the ore deposits are concentrated in Lok-Garabagh zone - Jurassic-Cretaceous island arc complex complicated by uplifts and depressions. The zone's typical feature consists in a placement of the copper-sulphide-polymetallic gold ore deposits in Shamkir (Gadabay deposit, etc.) and Aghdam (Gyzylbulag deposit, etc.) uplifts and the ironore and cobalt deposits in Dashkesan depression. These ore distribution specifics are undoubtedly related to the geological-tectonic and even more to the geodynamic conditions of their formation. Located in Dashkesan depression, the gabbro-diorite-granodiorite-granite intrusive used to be an ancient paleovolcano throughout the entire Jurassic and Early Cretaceous periods. The volcano's explosive and lava eruptions characterize it as a polyphase magmatic massif genetically related to the material complexes and iron-ore deposits: 1) Early Bathonian hematite 
deposits; 2) Middle Bathonian lapilli tuffs; 3) Callovian-Oxfordian Dashkesan iron-ore deposit and cobalt ores connected with gabbro-diabase dyke phase of the paleo-volcano. Such ratio of the area's iron-ore and gold-copper-sulphide deposits can be explained by possible presence of deeply buried Paleozoic ultrabasite plate within the structure of Dashkesan depression. Anatectic melting of the zone's granitoid formations then led to their interaction with this ultrabasite plate, thus enabling the formation of a hybrid magma with high iron content. Then the latter became subject to a liquation splitting process with emission of silicate and ore (iron-ore) melt. At this depth the high melting point could have favored the formation of high-temperature minerals in a bottom edge of the magma-generation center. Then such minerals could have been teared off by eruption and ejected on surface in the form of a breccia. This assumption is evidenced by the outcomes of research we implemented in the upper river basin of Ganjachay.

\section{Results}

On the northeastern slope of Lesser Caucasus mountains, in the eastern part of DashkesanGalakend synclinal trough (Lok-Garabagh structural zone), multiple fragments of different-sized ( $2 \times 3$ to $10 \times 12 \mathrm{~cm}$ ) burnt slaggy rocks (lavas) with typical porous texture and increased specific weight were detected in above flood-plain terraces and channel deposits of the upper reaches of Ganjachay and its minor tributaries. Detected fragments demonstrate miserable roundness, which points at proximity of native provenance areas. Psammitic fraction of the slaggy fragments was also established during area's panning activities, as a result, it was established that the share of such fragments reaches and exceeds $20 \%$ in most steam sediment samples.

Concentration areas of the fragments are structurally confined to the southeastern periphery of gentle Dashkesan syncline (central element of Dashkesan-Galakend depression) built by the Upper Jurassic formations traced from Shamkirchay river in the west through Ganjachay river in the east (Fig. 1). The trough is contoured along the bottom of Bathonian structural stage (porphyrites and their tuffs, tuff-conglomerates, tuff-breccias and lava-breccias, interleaved with tuffaceous sandstones and aleurolites), reflecting the changes occurred in the LokGarabagh zone's structural plan shortly before the beginning of Bathonian period.

In the bottom of unconformably bedding Bathonian formations, Bajocian volcanic complex has been revealed. Upper Jurassic structural stage fills in the trough's axis and outlines contours of the higherorder uplifts and deflections. The latter are mainly represented by Callovian-Oxfordian carbonates (up to $400 \mathrm{~m}$ ) unconformably overlapped by a Kimmeridgian volcanic complex built by diabase and andesite porphyrites, their tuffs, tuff-breccias and tuff-conglomerates, interleaved by calcareous sandstones (190-860 m).

In the central part of Dashkesan syncline there is the Late Jurassic gabbro-granite polyphase and polyfacies Dashkesan-Zurnabad intrusive, which had been formed through the following consequent phases (Kashkay, 1965): phase I - gabbro, gabbronorites, gabbro-diorites, quartz diorites, diorites (up to $20 \%$ ); phase II - granites, adamellites, tonalites, granodiorites (70\%); phase III - aplites, alaskites. In contemporary interpretation the intrusive is classified as a deep part of the volcanic center that used to be active during Middle-Upper Jurassic periods, while surrounding it Middle-Upper Jurassic lavas and pyroclasts are characterized as products of paleo-volcano's ejecta (Ismayil-zadeh, 2012).

The intrusive is surrounded by Middle and Upper Jurassic complexes containing relatively small stockwise bodies of the Upper Jurassic gabbro, gabbro-norites, gabbro-diorites, diorites (partly revealed in the river basin of Ganjachay), which are possibly the roots of parasitic eruptive channels, as well as the coeval dykes of diabases, gabbro-diabases, andesites, andesite porphyrites, diorites, quartz diorites and picrite-porphyrites.

According to the implemented reconstructions (Ismayil-zadeh, 2012), known iron-ore deposits of the Dashkesan ore cluster ${ }^{1}$ are interpreted as the ore bodies with volcano sedimentary origin confined to a paleo-volcanic center that used to be active during Middle and Late Jurassic periods together with silicate melt, as well as the ore melts - magnetite lavas, lapilli tuffites and hematite tuffs (Fig. 2).

Discovery of pyrite-porphyrite dykes inside and around the Dashkesan-Zurnabad intrusive allowed relating a genesis of its iron-ore deposits with presence of a buried allochthonous Paleozoic ultrabasite plate at the basement of Dashkesan paleo-volcano. Affected by melted palingenic magma, this plate had favored the formation of a hybrid magma which was then split into the silicate and iron-ore fusions. Presence of the abovementioned plate is confirmed by: a) outcropping of ultrabasites from under the Lower Bajocian basalts and andesibasalts $12-15 \mathrm{~km}$ to the southwest of Dashkesan-Zurnabad intrusive (upper reaches of Goshgarchay - Shamkirchay's right tributary); b) drilling in Novosaratovka village's vicinities (part of Shamkirchay uplift to the west of intrusive), which have revealed serpentinites at a depth of

\footnotetext{
${ }^{1}$ Many authors have previously characterized their genesis as of a skarn-metasomatic type (Kashkay, 1965; Geology of Azerbaijan, 2001)
} 
104-174 m from under the Bathonian deposits; and c) materials of geophysical research implemented in the river basin of Shamkirchay (Hasanov, 1985; Geology..., 2005).

Two trends of differentiation are established according to the A-S diagram (Fig. 3) built following the facial types of formations in Dashkesan-Zurnabad gabbro-diorite-granodiorite-granite intrusive and the dykes with picrite-porphyrite composition. One trend is ultrabasic and the other one is granitoid with formation of hybrid varieties of diorites, gabbro-diorites and quartz gabbro. This all goes to show that hybrid discrete magma could have been possibly formed during magmatic melt formation process, with ultrabasic ( $\mathrm{FeO} *$ content of up to $15 \%$ ) and acidic (granitoid) elements contributing to its generation. As stated above, the role of an ultrabasic component was played by the Paleozoic plate buried under the intrusive, which had determined the melting of picriteporphyrites (Ismayil-zadeh, 2012).
As concluded from the outcomes of petrogeochemical studies and seen from the AFM chart (Fig. 4), Middle Jurassic effusive and Late Jurassic intrusive rocks with gabbro-diorite-granodioritegranite composition correspond to the different types of the series: 1) granite-granodiorites and leucogranites correspond to high-aluminous calc-alkali gabbro series; 2) gabbro-diorites are closer to tholeitic series, and 3) effusive rocks are mainly closer to highaluminous tholeitic series.

Outcomes of petro-geochemical research reflect transformation of the calc-alkali formations of intrusive complex into the tholeitic series of volcanic complex during hybridism (fusion with ultrabasic material) process. At the same time presence of large 1-30 m thick deposits of stratal magnetitic bodies in the latter is most probably conditioned by a fact that the magma generation process had been contributed by a differently composed substance with high iron content.

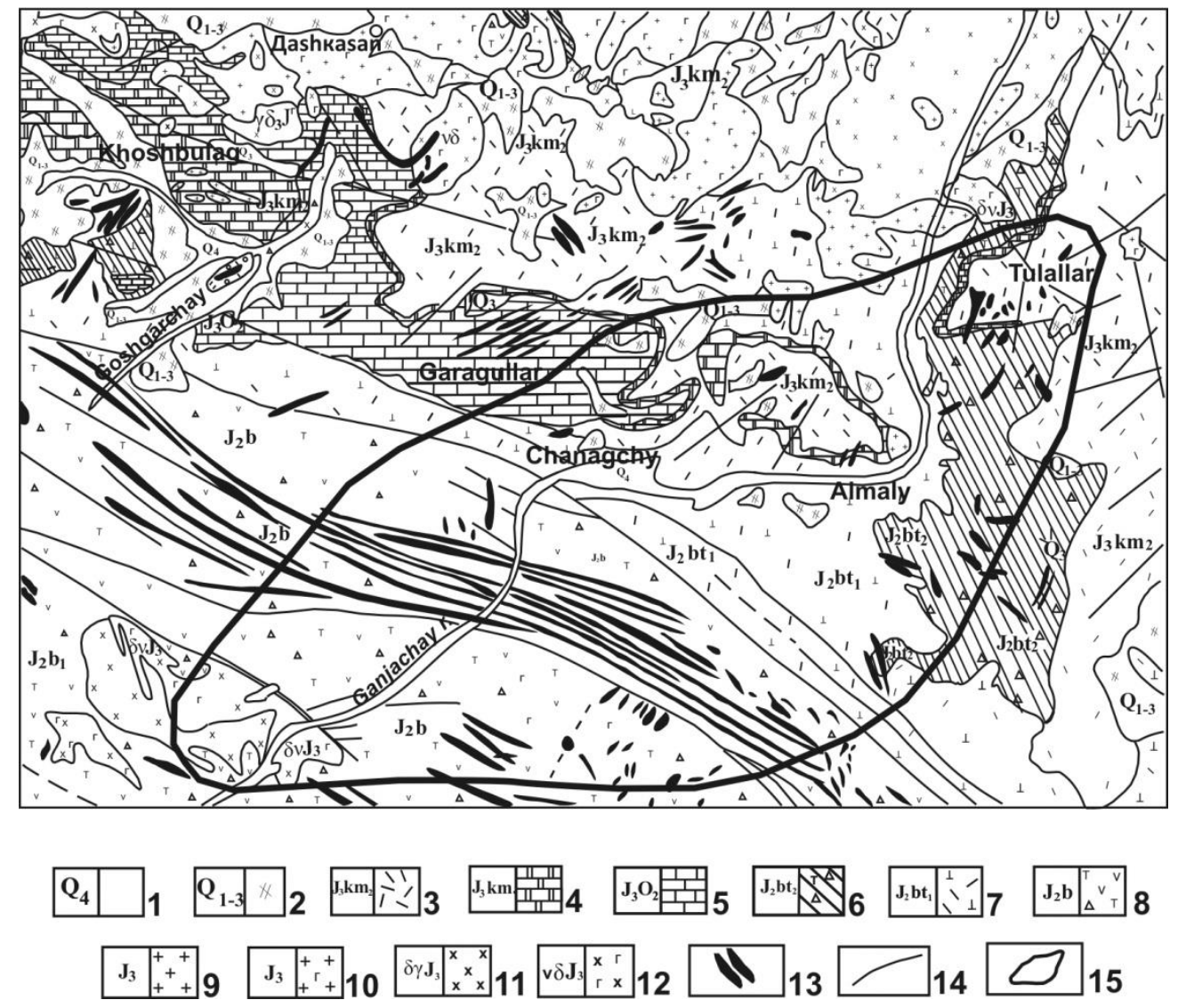

Fig. 1. Geological map o Goshgarchay and Ganjachay rivers interfluves.

1 - recent alluvial deposits; 2 - eluvial-deluvial deposits of the Pleistocene; 3 - the Upper Kimmeridgian: diabasic and andesite porphyrites, their tuffs, tuff breccia and tuff conglomerates, calcareous sandstones; 4 - the Lower Kimmeridgian: marmorized coral limestones; 5 - the Oxfordian: alternation of sandy and fragmental limestones with coral limestones; 6 - the Upper Bathonian: tuffites, tuffs, tuff sandstones, tuff conglomerates, tuff breccia and siltstones; 7 - the Lower Bathonian: porphyrites and their tuffs; tuff conglomerates, tuff breccia and lava breccia, layered by loose tuff sandstones; 8 - the Lower Bajocian: tuffs, tuff conglomerates and tuff breccia of andesites and andesi-dacites; 9-12 - intrusive rocks: 9 - diorites, quartz diorites and gabbro-diorites; 10 - gabbrodiorites; 11 - diorites and quartz diorites; 12 - gabbro and gabbro-diorites; 13 - dykes (diabases and gabbro-diabases, andesites, diorites and quartz diorites, picrite-porphyrites); 14 - faults; 15 - placer sampling area 


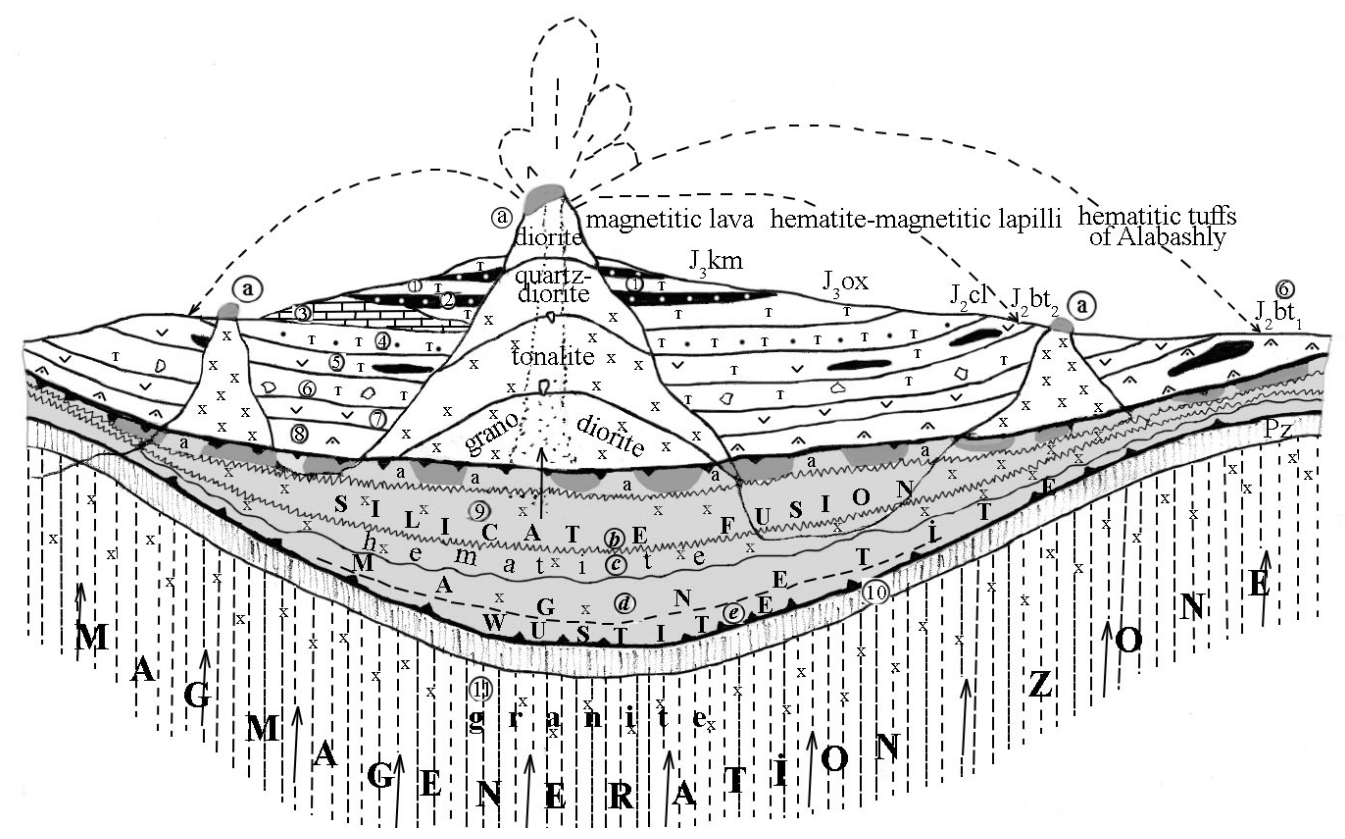

Fig. 2. Occurrence scheme of Dashkesan paleovolcano (dots and dotted lines) and formation of intrusive complexes (lines) during Late Jurassic period.

1 - tuffs and tuff-breccias, $\mathbf{J}_{3} \mathrm{~km} ; 2$ - magnetite lavas; 3 - sandstones, $\mathrm{J}_{3} \mathrm{Ox} ; 4$ - argillites and sandstones, $\mathrm{J}_{2} \mathrm{cl} ; 5$ - quartz tuffaceous sandstones with lenses of hematite-magnetite lapilli tuffs, $\mathbf{J}_{2} \mathrm{bt}_{2} ; 6$ - psammitic tuffs and tuff-breccias; hematite tuffs $\mathrm{J}_{2} \mathrm{bt}_{1} ; 7$ - quartz porphyries and their tuffs, $\mathrm{J}_{2} \mathrm{bj}_{2} ; 8$ - supposed buried allochthonous Paleozoic ultrabasite plate, liquation split into pieces during its interaction with granitoid magma: a) gabbroid ultrabasite, fragmented and weathered out on the crest of intrusive; b) silicate melt; c) hematite; d) magnetite; e) wustite; 9 - terrigenous-carbonate complex, Pz; 10 - palingenic granitoid

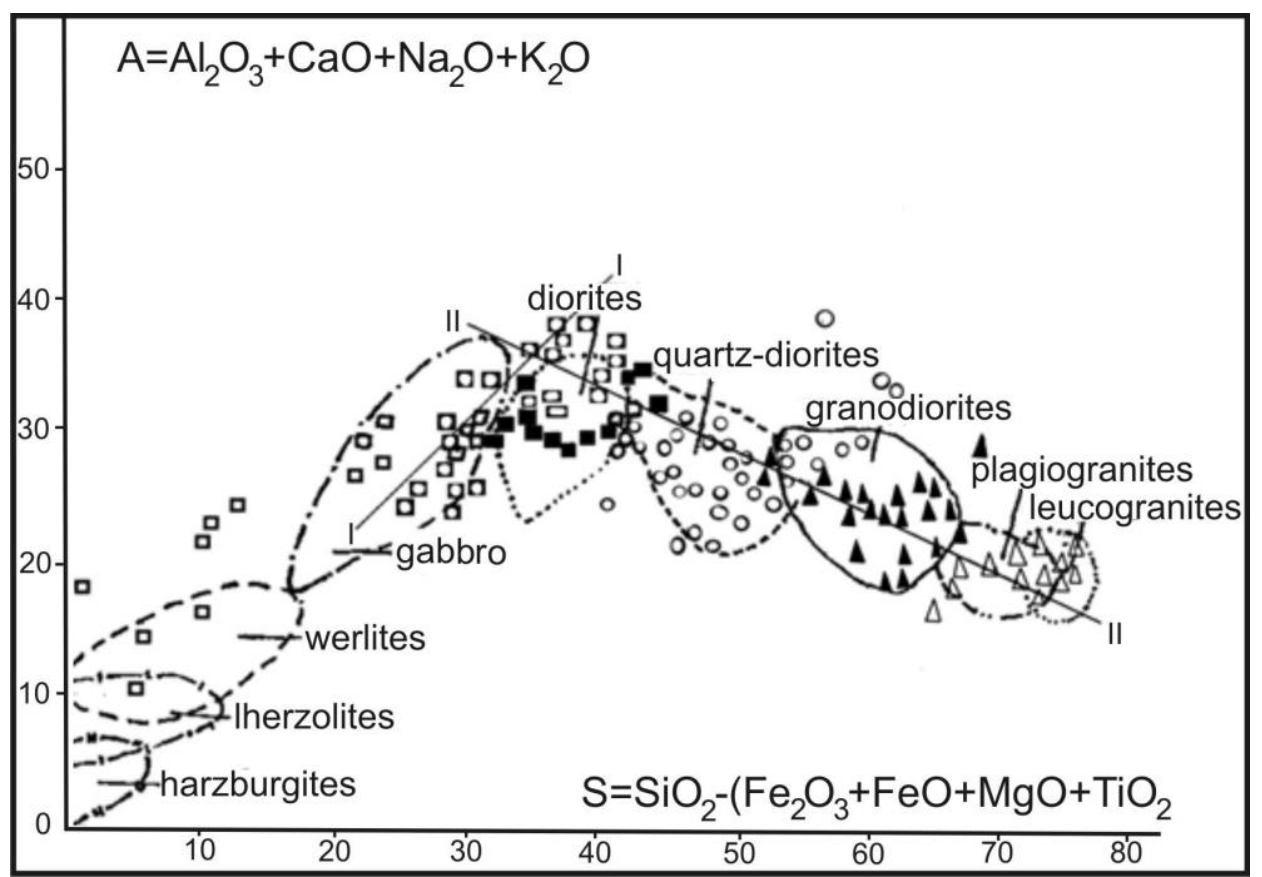

Fig. 3. A-S diagram. Position of Mesozoic granitoid intrusives of the Lesser Caucasus in the fields of statistical distribution of chemical composition of the rock main types 


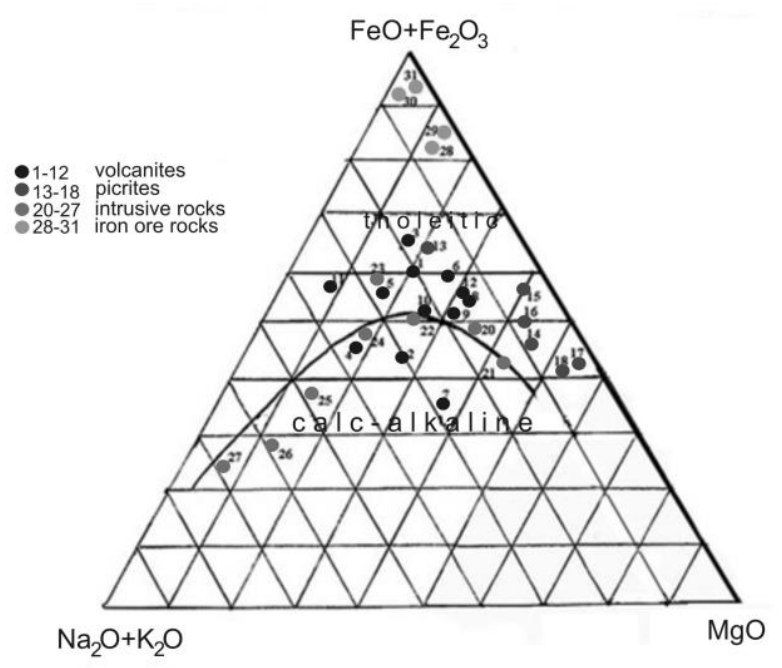

Fig. 4. Petro-geochemical parameters of Jurassic volcanogenic and intrusive complexes on AFM diagram

Such formations could be the subvolcanic bodies of picrite-porphyrites detected among diorites from Dashkesan intrusive and its surroundings. By composition these bodies correspond to the smelts from the ultrabasic formations.

Two types of the slaggy lavas were identified by testing of the selected samples, to include scoria with native iron and wustite content. It has been mentioned that it was the first discovery of scoria with wustite content in Azerbaijan (established according to X-ray phase analysis data).

1. Study of the first type of samples under optical (Polam R-312) and scanning electronic microscopes (REMMA-102-02) has shown that the following two types of ultrabasic formations contain native iron and magnetite in their structure: a - rocks with vitrobasalt basis and swells of olivine and pyroxene, and $b$ - rocks with plagioclase basis containing impregnations of olivine.

Rocks of the first variety have porous texture; pores have a round ellipsoidal shape often having membranous, cockade welts of hematite ("hydrohematite") along their outer contour. According to their $\mathrm{Al}_{2} \mathrm{O}_{3} / \mathrm{TiO}_{2}$ ratio such rocks belong to low-titanous picrites - komatiitic formations. Rock's clinopyroxene is represented by the individual tabular grains in the interstices of olivine. The latter forms the formation's groundmass (up to $60 \%$ ) appearing in the form of elongate to acicular (up to $200 \mathrm{mkm}$ ), differently oriented, fan-shaped discharges, looking similar to a structure of "spinifex" (Fig. 5, 6). Olivine interstices also contain fallow transparent glass in the form of strips outstretched along its crystals. This glass has the needles of crystallites that demonstrate poor reaction to a polarized light. Amount of the glass is rather few, not more than a third of the slide's total area. It demonstrates deflection which is considerably higher than that of the Canadian balsam. The spinifex structure was first described in 1982 in Australia (Arndt, Nisbet, 1982), detected among ancient lava flows with ultrabasic composition - komatiites with skeletal plate crystals of olivine and pyroxene detected in their upper segments.

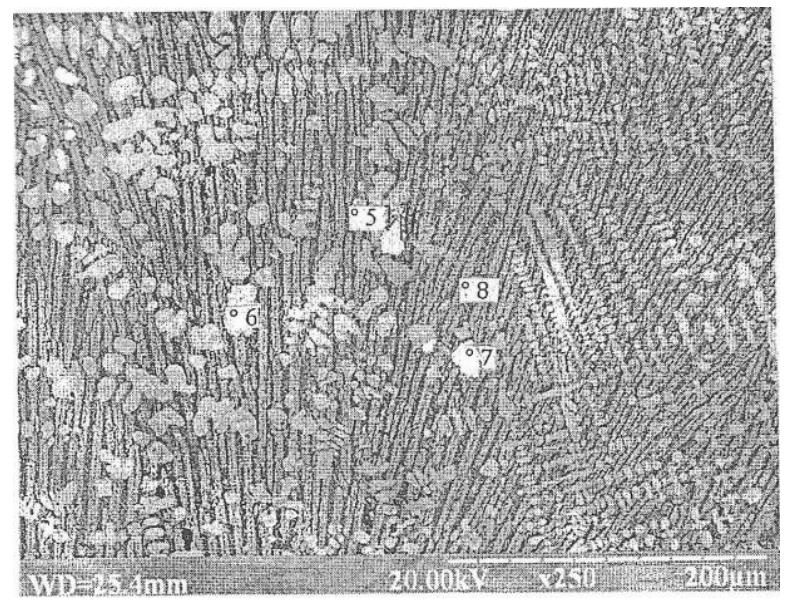

Fig. 5. Low-titanian picrate. Spinifex structure: 5 - clinopyroxene (black), 6 - magnetite (light-grey + "snowflakes"), 7 - native iron (white), 8 - elongated needle-like individuals of olivine (dark-grey)

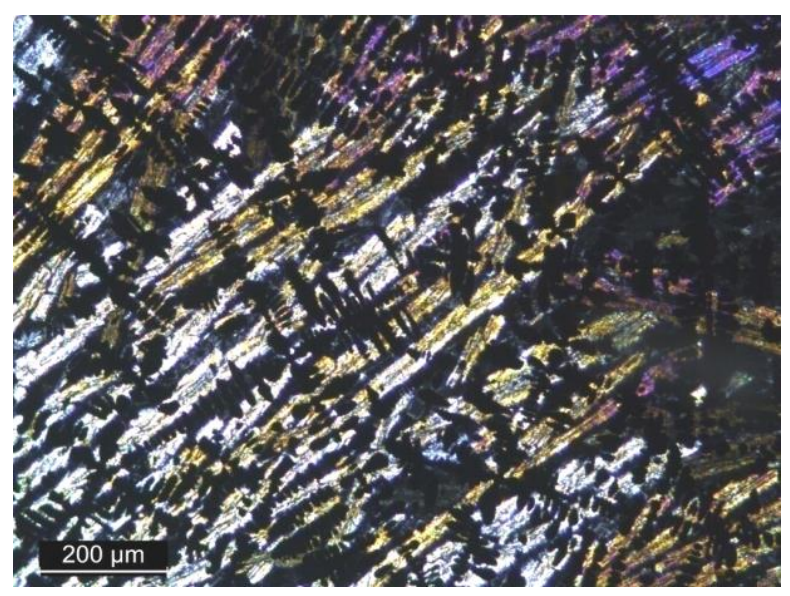

Fig.6. Komatiite-like rock. Spinifex structure: needle-like crystals of olivine (grey interference bodies), almost without interspaces. Image from optical microscope, magnification $45 \mathrm{x}$

Magnetite forms a complex network of original skeletal crystals (Fig. 7) developed separately from pyroxene, and this makes an impression that one structure is imposed over the other. The growth structure is similar to that of the snowflakes - classical example of skeletal crystals, where the rapid crystallization predominantly favors the formation of apical and costal forms with faces lagging behind in a growth rate (Popov, Shafranovsky, 1972). In our particular case it resulted in the formation of nearly flat, 0.3-0.8, rarely up to $1.6 \mathrm{~mm}$ large, quadriradiate skeletal crystals of magnetite. It's typical that the identical magnetite is present in the grains of olivine-hortonolite, detected as product of a solid solution breakdown in many Transvaal deposits (Ramdor, 1962). 


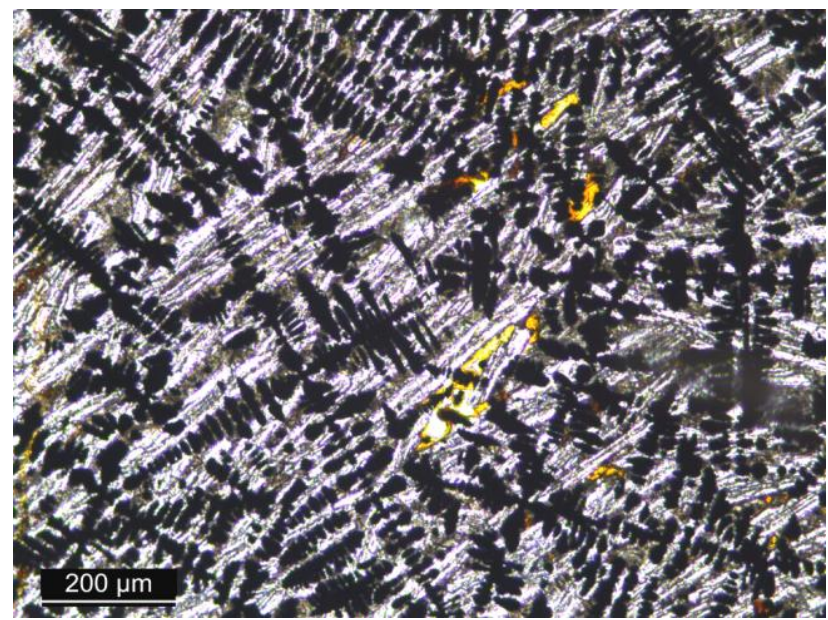

Fig. 7. Spinifex structure: skeletal crystals of magnetite (black "snowflakes") form similarity of net imposed on olivine needles. Image from optical microscope, magnification $45 \mathrm{x}$

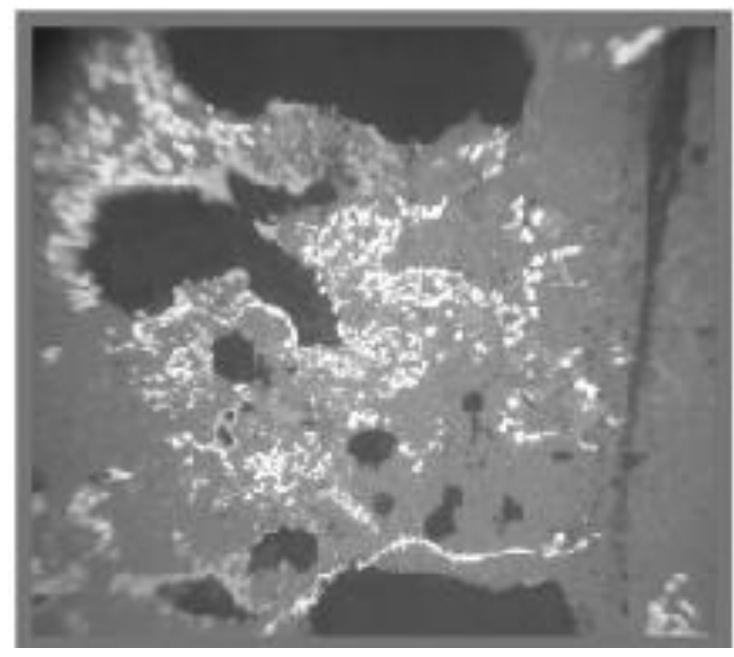

a

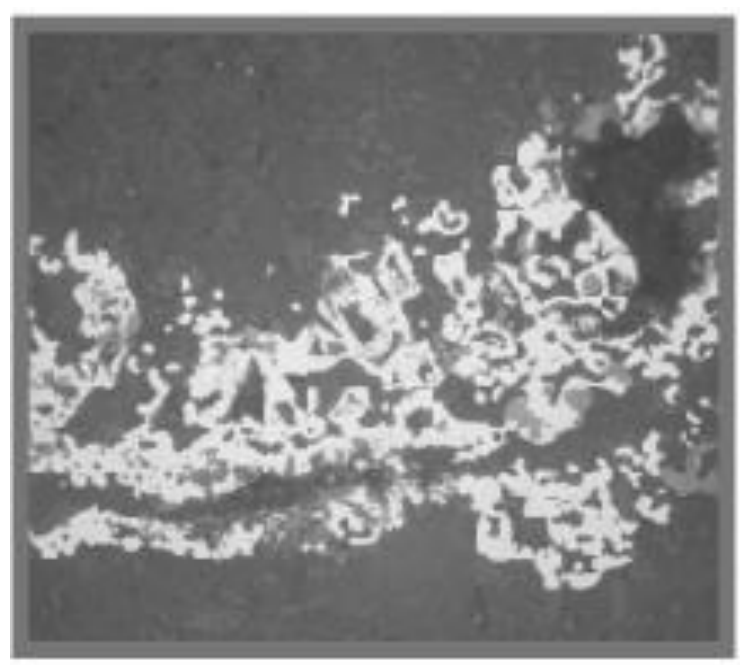

$\mathbf{b}$

Fig. 8. Native iron in polished sections: a - rich granular accumulation of native iron (white - emulsion impregnation, black pores, grey - iron hydroxides); polished sections, magnification $56.7 \mathrm{x} ; \mathrm{b}$ - more massive aggregate of iron intergrowths (white); polished section, magnification $132.3 \mathrm{x}$
Native iron forms thin $(0.005-0.01 \mathrm{~mm})$ and diffused impregnation: rarely detected are its' up to 5-10 mm large isometric isolated "spots" (Fig. 8). In reflected light this metal has a pinkish white with higher reflecting capacity of about $60 \%$, which is higher than that of pyrite. The iron is optically isotropous, magnetic, well-polished and dissoluble in the azotic acid.

Inside the rocks of the second variety (Fig. 9), olivine forms the irregularly shaped grains or the elongate needle-shaped individuals inside a mass of plagioclase with average-to-base composition. Magnetite, by which the iron hydroxide develops, is represented by isometric occlusions that equal $\geq 30 \%$ of the total rock volume.

By mineral composition these samples correspond to ultrabasic komatiite-like magnesianferruginous effusive (pyroxene komatiite - ?), the texture of which bears record to boiling and quick cooldown of the melt.

2. Dark, heavily magnetized, $1.0-1.5 \mathrm{~cm}$ thick swells are detected inside the second type rock's dense, grey and porous brecciated mass (macroscopically identified as burnt fragments from a melting center of the ironstones). Following oxides were detected in the wustite-containing sample according to results of $\mathrm{X}$-ray spectrometric analysis (mass.\%): $\mathrm{FeO}$ - 89.34; $\mathrm{SiO}_{2}-8.55 ; \mathrm{Al}_{2} \mathrm{O}_{3}-1.34 ; \mathrm{CaO}-0.77$.

As demonstrated by Debye powder diagrams, both samples contain certain amounts of wustite with two major reflexes $(d, \AA-\mathrm{I}, \%)$ observed: a) sample $1-2.489-59$ and 2.153 - 100; b) Sample 2 - $2.483-85$ and $2.148-100$. These parameters are close to the reference wustite properties accepted as JCPDS-ICDD \#\# 06-615, 46-1312.

It is known that wustite is formed at high temperatures in a strong reducing environment (Stryubel, Zimmer, 1987). At the same time due to its general instability the stoichiometric wustite is quite rare on our planet, mainly present in meteorites, lunar rocks or the kimberlite pipe diamonds. Some concentrations of this mineral are tellingly present in the deep-water hot brine deposits and iron-manganese concretions. Additionally, wustite is typically detected in the slags of steelmaking facilities (Stryubel, Zimmer, 1987). It was determined that wustite $\left(\mathrm{Fe}_{0.947} \mathrm{O}\right)$ decays into ferrous oxide $(\mathrm{FeO})$ and magnetite $\left(\mathrm{Fe}_{3} \mathrm{O}_{4}\right)$ when cooled down below $570^{\circ} \mathrm{C}$.

Also the magnetized sample varieties characterized by presence of a number of oxides (magnetite, hematite, maghemite, magnesium oxide and alumna) emerged in an oxidizing environment are detected. Some samples contain extrinsic siderophile elements (cobalt, chrome), manifesting a typomorphic relation with their contributor - iron from an ultrabasic source (Table). 
Chemical composition of rocks with wustite polluted by matter of host medium

\begin{tabular}{|c|c|c|c|c|}
\hline Минералы Образцы & 1 & 2 & 3 & 4 \\
\hline $\mathrm{SiO}_{2}$ & & & & \\
\hline $\mathrm{TiO}_{2}$ & 20.01 & 20.21 & 24.13 & 17.28 \\
\hline $\mathrm{Al}_{2} \mathrm{O}_{3}$ & $<0.001$ & $<0.001$ & $<0.001$ & $<0.001$ \\
\hline $\mathrm{FeO}$ & 7.20 & 5.89 & 9.57 & 8.12 \\
\hline $\mathrm{MnO}$ & 64.19 & 63.09 & 56.55 & $<1.27$ \\
\hline $\mathrm{MgO}$ & $<0.01$ & 0.50 & $<0.01$ & $<0.01$ \\
\hline $\mathrm{CaO}$ & 1.14 & 1.83 & 1.01 & 3.86 \\
\hline $\mathrm{Na}_{2} \mathrm{O}$ & 1.88 & 6.47 & 3.13 & 3.89 \\
\hline $\mathrm{K}_{2} \mathrm{O}$ & 2.80 & 0.96 & 2.85 & 0.72 \\
\hline $\mathrm{CoO}$ & 0.50 & 1.04 & 0.69 & 0.37 \\
\hline $\mathrm{Cr}_{2} \mathrm{O}_{3}$ & $<0.001$ & $<0.001$ & $<0.001$ & 0.72 \\
\hline п.П.П. & 1.31 & $<0.001$ & 1.10 & 3.07 \\
\hline Сумма: & 0.97 & 0.01 & 0.87 & 100.00 \\
\hline
\end{tabular}

In our opinion, studied samples are actually the activity products of deep magmatic chamber with quartz diorite-diorite composition, in which the ironbearing mass used to melt forming the discovered concentrations of wustite.

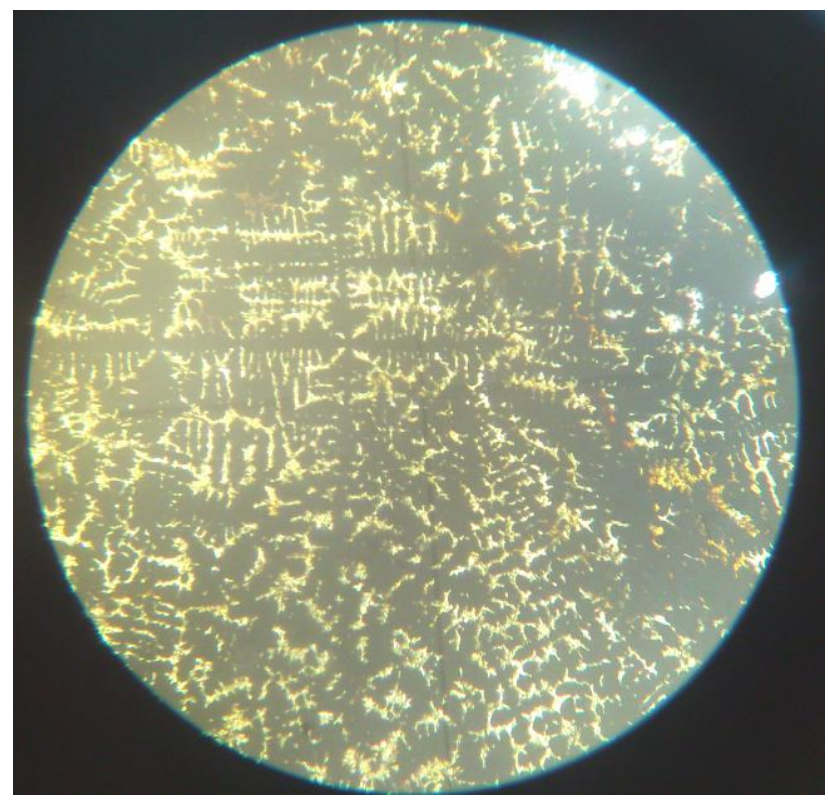

Fig. 10. Microstructure corresponding to the assumed breakdown of a wustite-based solid solution. White - iron oxide $\mathrm{FeO}$; grey - magnetite $\mathrm{Fe}_{3} \mathrm{O}_{4}$ (magnification: 8x9)

Typical solid phase decay of the magnetized samples into $\mathrm{FeO}$ and $\mathrm{Fe}_{3} \mathrm{O}_{4}$ is reflected in wustite's surface microstructure (Fig. 9), where the following two types of decay phenomenons were clearly established: a) radially fibrous decay of a substance in the crystal's central segment; and b) decay in two mutually perpendicular directions possibly related to a cubic structure of wustite.
Study of the provided material brings us to a conclusion that wustite was surfaced by a hybrid magma with quartz diorite-diorite composition formed during the replacement of palingenic granitoid magma with serpentinized rocks of the buried ultrabasic plate.

Formation of scoria with wustite and komatiitic structure can be imagined as follows: at the end of the Paleozoic period an ultrabasic plate - residual of the Paleozoic oceanic crust that used to be buried under Mesozoic volcanosedimentary complex, became obducted on the pre-Alpine substrate of Lok-Garabagh zone during closure of the oceanic basin of Paleotethys (Ismayil-zadeh, 2012). Later in the light of intensive Mesozoic island arc magmatism developed on Mesotethys periphery and accompanied by the formation of palingenic granitoid magma, the latter started to interact with buried allochthonous ultrabasic plate represented by serpentinites and ultrabasites with $\mathrm{FeO}$ content of over $15 \%$. Enriched by geochemical elements of the both types of magma, this molten material became subject to a liquation splitting into the silicate and iron-ore fractions. Later the magmas that were saturated with hydrogen-rich fluids (emerged during iron's oxidation), became accumulated in the upper parts of the magmatic chambers together with fluorine and chlorine. Known to be quite intensive in the replacement zone of granitoidal series into the hybrid diorites, this process was accompanied by discharge of the iron-ore fraction within the structure of hydrogen-halogen emanations of a number of siderophile elements (e.g. cobalt, chrome, nickel and platinum that are currently present in the ironore structure). Such gas-abundant magma used to be ejected together with tuff-breccias, tuffs and 
fragments of deep magma generation chamber containing wustite and spinifex-structured rocks, and then outflew as an essentially magnetite fusion. Influence of the acidic magma upon the ultrabasic (serpentinized) allochthonous plate used to be most intensive in the bottom parts of the plate, and reduced towards the plate's top edge. Emerged hybridism has reached its maximum during development of the dioritic facies which are now detected in the structure of most of the region's intrusives. It is only on the topmost edge of the plate that the gabbroidal varieties of ultrabasites have remained with signs of the initial ultrabasic formation, including skeletal forms of olivine and chrome-spilenites with complexes of secondary minerals - tremolite, talc, prehnite and chlorite.

\section{Conclusions}

Therefore, it should be assumed that the studied samples represent fragments of the deep magmatic chamber (melted fragments of granitoids with wustite erupted during paleovolcanic eruptions), i.e. ul-

\section{REFERENCES}

Arndt N.T., Nisbet, E.G. What is komatiits? In: Komatiites. G.Allen and Unwin. London, 1982, pp. 19-28.

Geology of Azerbaijan. V. III. Magmatism (ed. Alizadeh Ak.A.). Nafta-Press. Baku, 2001, 433 p. (in Russian).

Geology of Azerbaijan (ed. Khain V.E., Alizadeh Ak.A.).V. IV. Tectonics. Nafta-Press. Baku, 2005, 505 p. (in Russian).

Hasanov T.A. Ophiolites of the Lesser Caucasus. Nedra. Moscow, 1985, 240 p. (in Russian).

Ismail-zadeh A.D. A new look to the formation of iron ore deposits in the Dashkesan trough of the Lesser Caucasus: Proceedings of ANAS, The sciences of Earth, No. 4, 2012, pp. 33-43 (in Russian)

Kashkay M.A. Petrology and metallogeny of Dashkesan and other iron ore deposits of Azerbaijan. Nedra. Moscow, 1965,888 p. (in Russian).

Popov G.M., Shafranovsky I.I. Crystallography. Vysshaya shkola, Moscow, 1972, 353 p. (in Russian).

Ramdor P. Ore minerals and their intergrowths. Foreign literature publishing house. Moscow, 1962, $1132 \mathrm{p}$.

Stryubel G., Zimmer Z.H. Mineralogical dictionary. Nedra. Moscow, 1987, 494 p. (in Russian). trabasic rocks of the allochthonous plate and the margins of magma generation center, which had been re-crystallized into komatiites (?). The fact that there are practically no volcanic slags in the alluvial deposits of Goshgarchay (the river that directly crosses the Dashkesan intrusive and its hosting Upper Jurassic formations), and that there is a large amount of slags in the southeast in the riverbed of Ganjachay and its minor tributaries, speaks for their ejection as a result of Late Kimmeridgian explosion of the parasitic cone(s) of Dashkesan paleovolcano.

The strata of diabase and andesite porphyrites, tuffs and tuff-breccias forms highest elevations of the both riverbanks of Ganjachay and gets ruptured by Tulallar and other minor diorite-quartz diorite and gabbro-diorite intrusives (possibly the roots of parasitic cones). This strata is possibly that very main basis, erosion of which had promoted the removal of volcanic slags with wustite and native iron, and their re-deposition in a contemporary alluvium. However, this question requires more detailed investigations.

\section{ЛИТЕРАТУРА}

Arndt N.T., Nisbet E.G. What is komatiits? In: Komatiites. G.Allen and Unwin. London, 1982. pp. 19-28.

Ramdor P. Ore minerals and their intergrowths. Foreign literature publishing house. Moscow, 1962, $1132 \mathrm{p}$.

Геология Азербайджана (под ред. Ак.А.Ализаде). Т.ІІІ. Магматизм. Nafta-Press. Баку, 2001, 433 c.

Геология Азербайджана (под ред. В.Е.Хаина, Ак.А.Ализаде). T.IV. Тектоника. Nafta-Press. Баку, 2005, $505 \mathrm{c}$.

Гасанов Т.Аб. Офиолиты Малого Кавказа. Недра. Москва, $1985,240 \mathrm{c}$.

Исмаил-заде А.Д. Новый взгляд на формирование железорудных месторождений Дашкесанского прогиба Малого Кавказа. Известия НАНА, науки о Земле, No. 4, 2012, с. 33-43.

Кашкай М.А. Петрология и минералогия Дашкесана и других железорудных месторождений Азербайджана. Недра. Москва, 1965, 888 с.

Попов Г.М., Шафрановский И.И. Кристаллография. Высшая школа. Моква, 1972, 353 с.

Штрюбель Г., Циммер 3.Х. Минералогический словарь. Недра. Москва, 1987, 494 с.

\title{
АКЦЕССОРНЫЕ МИНЕРАЛЫ КАК ИНДИКАТОРЫ ГЛУБИННОСТИ МАГМОГЕНЕРАЦИИ И РУДОГЕНЕЗА В ПРЕДЕЛАХ ДАШКЕСАНСКОГО РУДНОГО РАЙОНА (МАЛЫЙ КАВКАЗ, АЗЕРБАЙДЖАН)
}

\author{
Исмаил-заде А.Д., Кенгерли Т.Н., Ахмедов А.М., Амиров А.С. \\ Институт геологии и геофизики НАНА \\ AZ1143, Баку, просп.Г.Джавида, 119 : arifismail@mail.ru, tkangarli@gmail.com, \\ ahmedov.geo@gmail.com
}

\begin{abstract}
Pезюме. Вюстит (на территории Азербайджана впервые установлен авторами публикации) и самородное железо обнаружены в шлакообразных обломках пород (вулканических шлаков) из речного аллювия и надпойменных террас р.Гянджачай и ее мелких притоков на восточной периферии Дашкесанского прогиба Лок-Гарабагской зоны Малого Кавказа. Прогиб располагается в междуречье рр. Шамкирчай (на западе) и Гянджачай (на востоке) и оконтуривается по подошве батского структурного этажа (порфириты и их туфы, туфоконгломераты, туфобрекчии и лавобрекчии, прослоенные туфопесчаниками и алевролитами), отражая изменения структурного плана Лок-Гарабагской зоны в предбатское время. Шлакообразные обломки - это обож-
\end{abstract}




\title{
Geology and geophysics
}

женные плотные комковатые пузыристые породы двух типов: 1 - базальтоиды со специфичной структурой спинифекс и содержанием самородного железа и магнетита и 2 - гранитоиды с включениями обломков вюстита различного размера, а также магнетита, маггемита и др. В первом случае металлосодержащие породы отвечают низкотитанистым пикритам и коматиитоподобным магнезиально-железистым образованиям (пироксеновым коматиитам -?), во втором - диоритам и кварцевым диоритам. Материалы проведенных исследований приводят к выводу, что вюстит и металлосодержащие породы вынесены на земную поверхность гибридной магмой кварцдиорит-диоритового состава, образовавшейся в процессе смешения палингенной гранитоидной магмы с серпентинизированными породами погребенной ультраосновной пластины. При этом исследованные образцы представляют собой фрагменты глубинного магматического очага - перекристаллизованные в коматииты (?) ультраосновные породы и фрагменты краевых зон очага магмогенерации - оплавленые гранитоиды с вюститом, магнетитом, маггемитом и др., выброшенные в процессе эксплозивной деятельности палеовулканов.

Ключевые слова: юрский магматизм, вулканический илак, самородное железо, вюстит, структура спинифекс

\section{KIÇİK QAFQAZIN DAŞKəSəN FİLIZ RAYONUNDA MAQMAGENERASIYYA Və

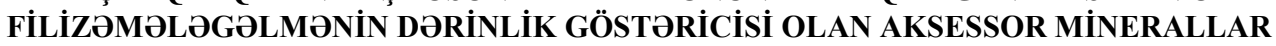

\author{
İsmayıl-zadə A.C., Kəngərli T.N., Ohmədov Ә.M., Omirov A.S. \\ Azarbaycan Milli Elmlar Akademiyası Geologiya va Geofizika İnstitutu \\ AZ1143, Bakı, H.Cavid prosp., 119 : arifismail@mail.ru, \\ tkangarli@gmail.com, ahmedov.geo@gmail.com
}

Xülasə. Azərbaycan ərazisində müəlliflər tərəfindən ilk dəfə müəyyən edilmiş vüstit, həmçinin sərbəst dəmir Kiçik Qafqazın Lök-Qarabă̆ zonasına aid Daşkəsən əyilməsinin şərq kənarında Gəncə çayı və onun kiçik qollarının çaylaqüstü terras və çaybasar allüvisindən əldə edilmiş şlakabənzər süxur (vulkanik şlak) qırıntılarında aşkar edilmişdir. . Qərbdə Şəmkirçay və şərqdə Gəncəçayla hüdudlanan əyilmə porfiritlər və onların tufları, tuf-qumdaşı və alevrolit təbəqələri ilə laylanmış tuf-konqlomerat, tuf-brekçiya və lava-brekçiyalardan ibarət bat struktur mərtəbəsinin (porfiritlər və onların tufları, tuf-konqlomeratlar, tuf-qumdaşı və alevrolit təbəqələri ilə laylanmış tuf-brekçiya və lava-brekçiyalar) dabanı üzrə ayrılmaqla Lök-Qarabağ zonasının batönü dövrdə struktur planının dəyişilməsinə dəlalət edir. Bu qırıntılar iki tip yandırılmış, sıx, kəsəkli, qabarıqlı süxurlardan ibarətdir: 1 - spesifik srinifeks strukturuna malik, sərbəst dəmir və maqnetit saxlayan bazaltlar; 2 - müxtəlif ölçülü vüstit qırıntıları, həmçinin maqnetit, maqgemit və s. saxlayan qranitoidlər. Birinçi halda metalsaxlayan süxurlar aztitanlı pikritlərə və komatiitəoxşar maqnezial-dəmir əmələgəlmələrinə (piroksenli komatiitlər və b.) cavab verir, ikincisində isə - diorit və kvarslı dioritlərə uyğun gəlir. Aparılmış tədqiqatların nəticələri göstərir ki, vüstit və metalsaxlayan süxurlar kvarsdiorit-diorit tərkibli hibrid maqması ilə yer səthinə çıxarılmışdır. Guman edilir ki, bu cür maqma palingen qranitoid maqmasının basdırılmış ultraəsasi tərkibli lövhənin serpentinitləri ilə qarışma prosesi nəticəsində əmələ gəlmişdir. Tədqiq edilmiş nümunələr paleovulkanların eksploziv fəaliyyəti prosesində dərinlikdə yerləşən maqma ocağının yer səthinə çıxarılmış fraqmentləri olmaqla, ultraəsasi süxurların yenidən kristallaşması nəticəsində komatiitlərə (?) və maqmagenerasiya ocağının kənar zonasına aid olan, özündə vüstit, maqnetit, maqgemit və s. saxlayan əridilmiş qranitoidlərə cavab verir.

Açar sözlor: Yura maqmatizmi, vulkanik şlak, sərbəst dəmir, vüstit, spinifeks strukturu 